\title{
NEWS
}

\section{Excavations of an Early Neolithic Site at Tăşnad, Romania}

\author{
Ciprian Astaloş, ${ }^{*}$, Ulrike Sommer ${ }^{\dagger}$ and Cristian Virag*
}

\section{Location}

The town of Tăşnad, in north-west Romania, is situated at the western end of the Tăşnad Hills which rise to a height of up to $230 \mathrm{~m}$ above sea-level; the site 'Sere' is situated south-west of the town near a thermal spa on the banks of the Cehal river, a tributary of the Ier. The Cehal valley opens towards the Ier and Someş plains which form the north-easternmost part of the Great Hungarian Plain, a marshy area until the large-scale drainage-works of the 19th and 20th centuries. Even today, the Cehal valley is quite swampy, especially at the confluence with the Ier. The Austrian military maps demonstrate large-scale forest-clearance during the last three centuries; at the end of the 18th century, the site itself was still forested. Several prehistoric sites from different periods are located on the first and second terraces of the Cehal, at altitudes of around $140 \mathrm{~m}$.

\section{Discovery}

In the 1970s, a canal was built to divert the waters of the Cehal river, which led to the discovery of 'Sere' by Neța Iercoşan who started excavations there in 1989 (Iercoşan, 1995), later continued between 1995 and 1999. An

\footnotetext{
* Satu Mare County Museum, Satu Mare, 21 Vasile Lucaciu, 440031 Romania astalos_ciprian@yahoo.com, cristi_smro@yahoo.com

† UCL Institute of Archaeology, London WC1H OPY, United Kingdom u.sommer@ucl.ac.uk
}

Early Neolithic pit-house and numerous pits were discovered on this occasion, as well as human remains. Because of the rapid expansion of the Tăşnad spa, surrounding a thermal well, János Németi and Ciprian Astaloş carried out rescue excavations in 2001-02 and, since 2004, Cristian Virag has been directing further, ongoing, rescue excavations with research extended (from 2006) to the second terrace of the Cehal, where features from the Late Bronze Age have been discovered.

\section{Archaeology}

The site 'Sere' contains settlement remains from the Neolithic, the Bronze Age and the Roman period. The most numerous features belong to the Early Neolithic Criş culture (Fig. 1) and consist of pits, pit-houses, graves, hearths, ovens and post-built houses. In many areas, these features are overlain by an occupation layer which likewise contains numerous finds. The Neolithic remains were found at depths of between 0.6-1.2m, meaning that they have been protected from disturbance by modern agriculture and are thus very well preserved. The excavated Criş artefacts consist mainly of pottery sherds, chipped stone tools, axes, querns, anthropomorphic and zoomorphic figurines (Băcueț-Crişan and Virag, 2007), clay stamps (pintaderas), clay altars, loom-weights and spindle-whorls. The head of one human figurine is triangular in shape, with two incised lines marking the eyes and the nose in relief 


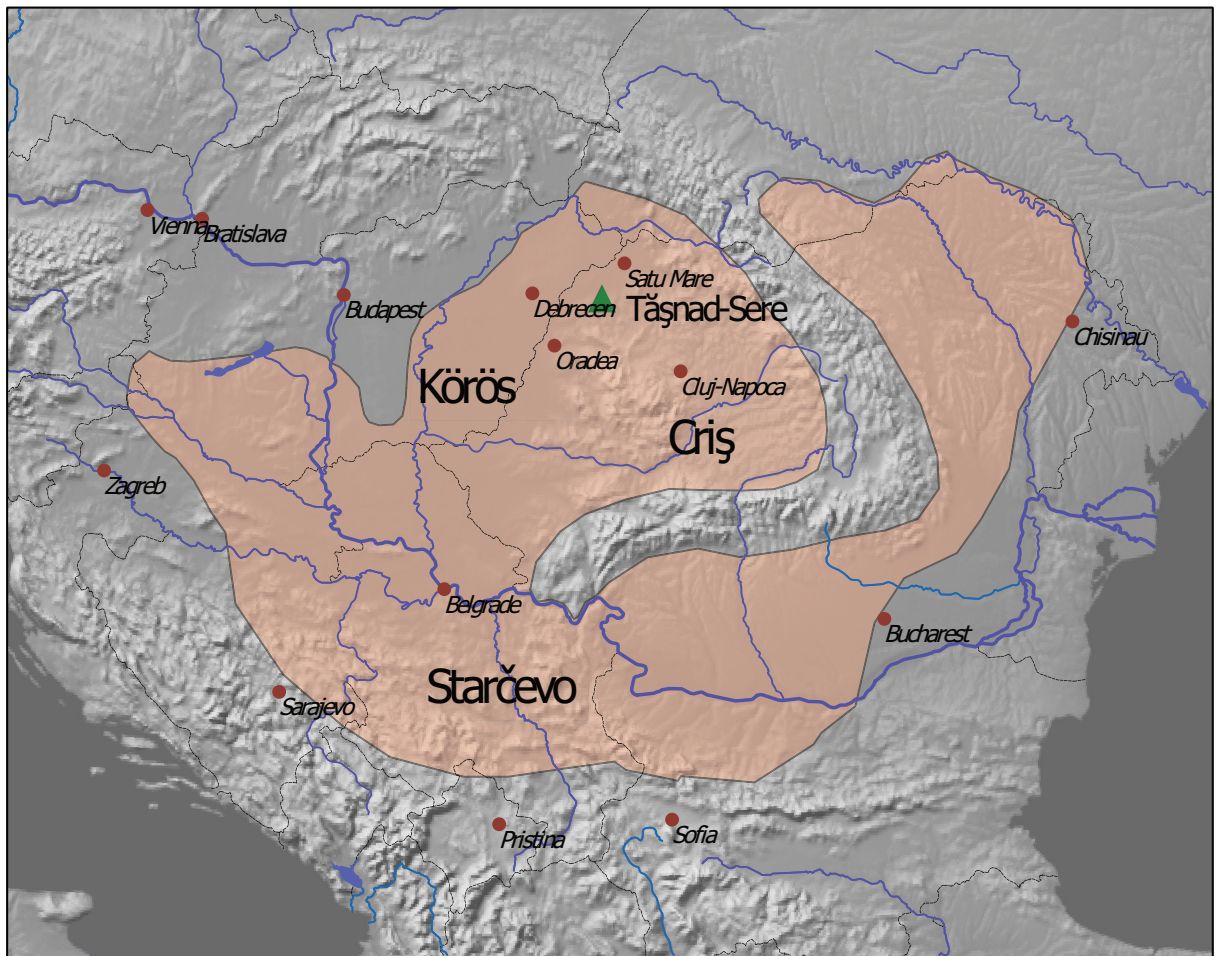

Fig. 1: Distribution of the Criş/Starčevo/Körös culture and location of Tăşnad Sere (map: Susanne Geck).

(Fig. 2). The posterior part of a steatopygian figurine was also found. There are numerous bones of cattle, pig, ovicaprids and wild boar, as well as aurochs' horn-cores and red deer antlers.

Several houses were found in the course of the excavations - three of which were marked by post-holes (Fig. 3). Feature $100 / 2009$, measuring $8.5 \times 6 \mathrm{~m}$, had posts along the walls, with a central row of three to support the roof. On its southern side, three post-holes seem to have belonged to an annex. The other two post-built houses were of similar size $(9 \times 10 \mathrm{~m}$ and $7.5 \times 7 \mathrm{~m})$ and construction. Another house was partly dug into the soil. It was oval in shape, with the roof supported by seven posts; an oven had been dug into its subterranean wall. Inside, enormous quantities of pottery, burnt bone and ash were discovered, with numerous loom-weights indicating its use as a weaving hut. As flax is best worked when slightly wet, semi-subterranean houses were used for this purpose up into the Middle Ages. A second semi-subterranean house could only be partly excavated. Large oval and irregular pits with post-holes, traditionally interpreted as pit-houses, were also found - one of which contained further loom-weights.

Four single graves of the Criş culture have been excavated at Tăşnad. Three of them were located in proper grave-pits, but the other was buried in a feature that was probably a refuse pit or a pit-house. All the skeletons lay in a contracted position on their left sides. One grave contained two obsidian blades; the other burials had no grave goods at all.

There are also later features at Tăşnad Sere, dating to the Middle Neolithic Pişcolt culture, the Late Copper Age Coțofeni culture and the Przeworsk culture of the Roman period. Excavation reports from Tăşnad have been published as short reports in the Chronicle 


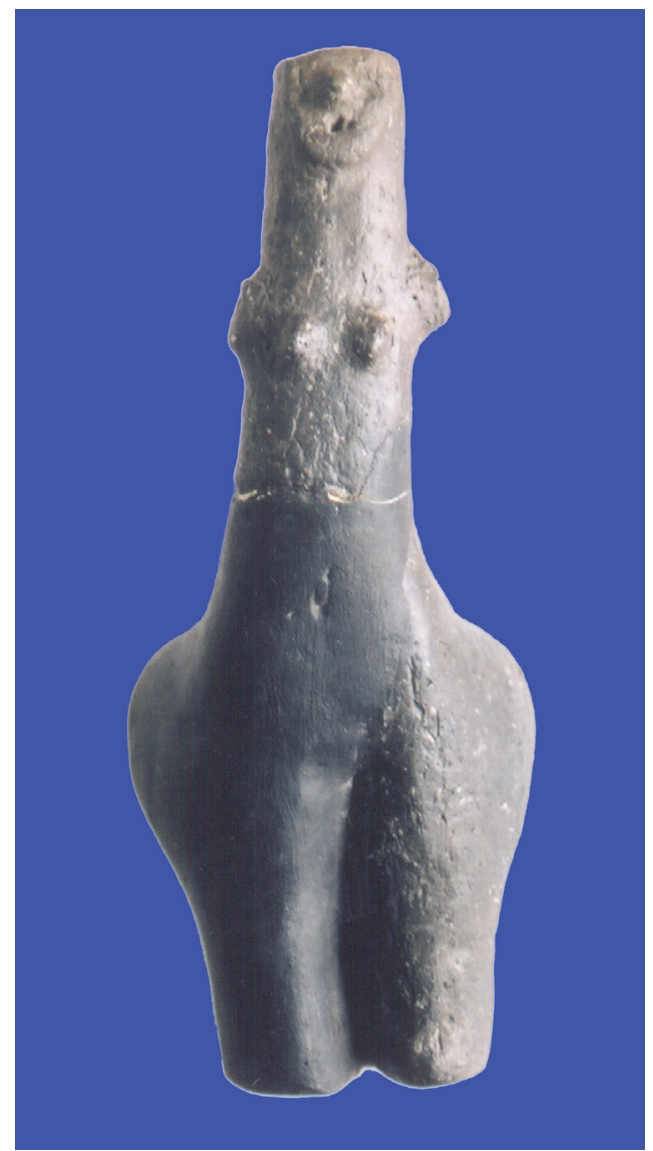

Fig. 2: Anthropomorphic figurine from Tăşnad Sere (photo: Cristian Virag).

of Archaeological Research of Romania (www. cimec.ro), but a detailed publication of the discoveries remains a task for the future.

Based on the pottery style, the site of Tăşnad Sere can be attributed to phases IIIB and IVA of the Criş culture, according to the chronological system of Gh. Lazarovici (1984). The Criş culture, known as Starčevo in Serbia, Bosnia and Macedonia, and as Körös in Hungary (Fig. 1), is the oldest Neolithic culture of the Balkans and the Pannonian Basin, dating to 6300-5200 BC (Schubert, 1999). It is characterised by organic tempered pottery, decorated with painted and incised patterns. Both tell settlements and open settlements are known, with the houses normally consisting of small, one- room, rectangular structures, built of wattle and daub, containing a hearth (Lazarovici and Lazarovici, 2006; 2011). Emmer, einkorn and millet were cultivated, as well as lentils, field peas, opium poppy and flax, but wild plants also formed an important part of the diet (Gyulai, 2010). Animal-bone assemblages are normally dominated by ovicaprids, followed by cattle and pig, as well as numerous wild mammal species. Birds, fishes (Kovács et al., 2010: 248f.) and molluscs (Gulyás et al., 2007) were also exploited.

In north-west Romania, the Neolithization process (understood as the appearance of pottery and ground stone tools) took place later than in the neighbouring areas of central Transylvania, the Banat and the Tisa valley, during the period Criş IIIB-IVA. The Criş communities may have arrived in Tăşnad from central Transylvania, reaching the Sălaj area, then following the Barcău and Ier valleys, and maybe the Crasna valley. Settlements of Criş type are known from Sălacea, Tarcea, Voievozi, Văşad, Pişcolt, Berea and Urziceni. The material uncovered at Tăşnad is also similar to contemporary sites in both north-western Romania (Homorodu de Sus, Homorodu de Mijloc, Zăuan, Suplacu de Barcău/Porţ and Călineşti Oaş) and northeastern Hungary (Méhtelek and Nagyecsed), towards the west. Thus, Németi (1999) has claimed that the first agricultural settlers of the middle Tisa valley arrived from the south, following the river.

Pottery forms found at Tăşnad include characteristic biconic vessels with a rounded, slightly everted rim, biconic bowls, biconic jars with a short neck, and vessels with a hollow pedestal. The majority of the pottery from Tăşnad is tempered with sand, grog, silt and chaff, which is characteristic for the evolved phases of the Criş culture. Because of the use of silty clay and organic temper, the pottery is very soft and has a 'soapy' surface, a phenomenon that starts in the later phases of the Criş culture (IIIB-IVA). This dating is supported by sherds with incisions below the rim, as such incised ornament is typical for 


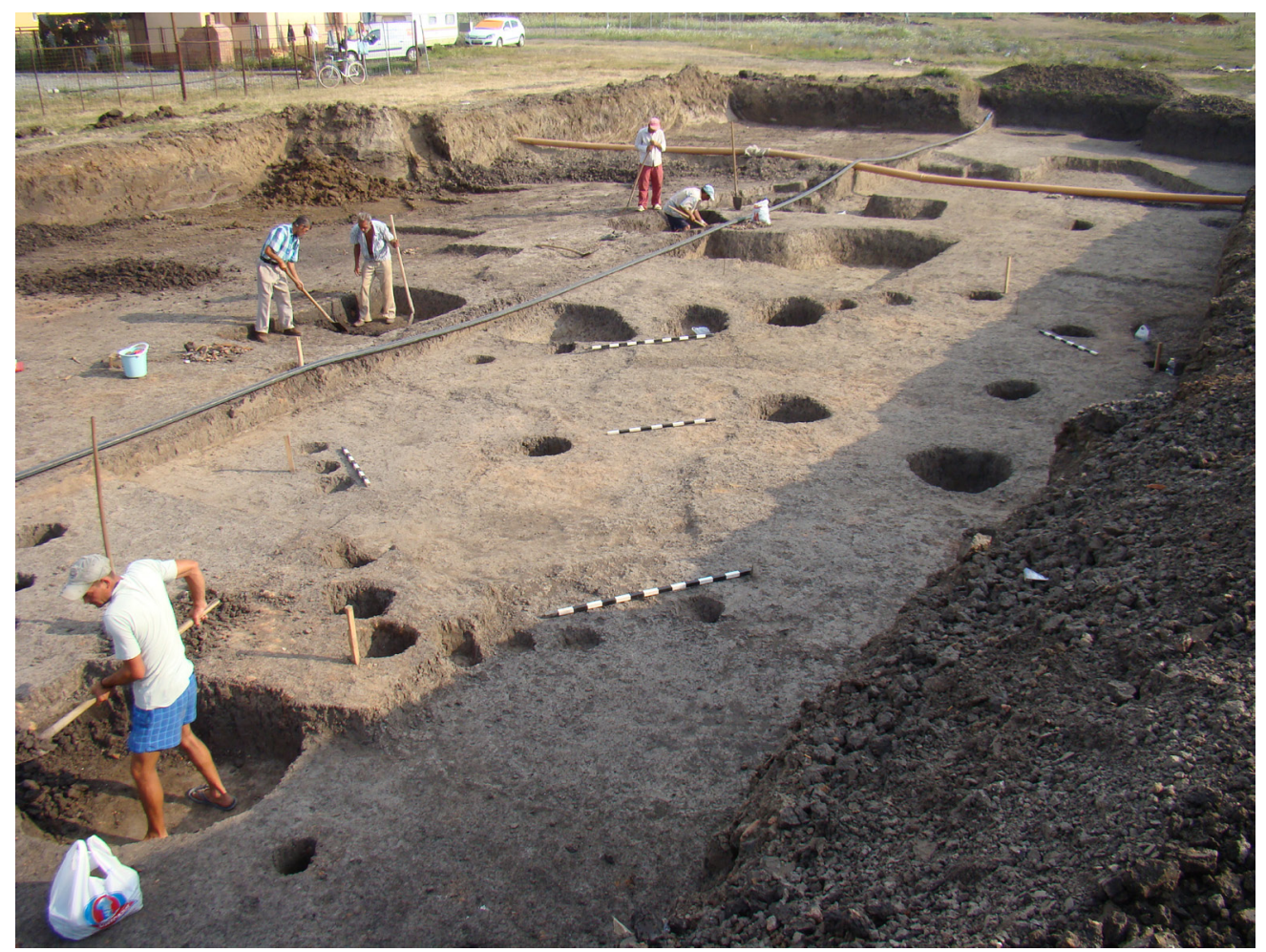

Fig. 3: Excavation of Criş houses at Tăşnad Sere, in 2009 (photo: Cristian Virag).

the IIIB-IVA phases of the culture. There are also polished ornaments, barbotine decoration and fingernail imprints.

\section{UCL Institute of Archaeology excavations}

In summer 2011, Ulrike Sommer visited the site and decided that the existence of a thick, well-preserved, occupation layer made Tăşnad Sere ideal for research on deposition processes and the activity structure of a Criş settlement. In addition, the large-scale rescue excavations by the Satu Mare County Museum would enable a small, detailed, research excavation to be placed in the wider context of the overall settlement-site.

Early Neolithic settlements in both southeast and central Europe normally contain numerous pits and, in flat settlements, these can often be the only surviving structures. Since the 1970s, finds in the long pits along the sides of Linearbandkeramik (LBK) houses have been used to date these houses which are normally only represented by postholes, as the original Neolithic surface has been eroded. Complex chronologies of settlement development (Stehli, 1994), and of the development of individual settlements (Lüning, 2005), have thus been developed. In southeast Europe, on the other hand, it has often been thought that irregular pits could have served as dwellings (pit-houses or sunken houses), especially in the early phases of settlements. Finds in these pits have thus been seen as in situ refuse which could be used for dating their use as houses. However, in 1988, Harald Stäuble conducted a detailed study of the distribution of the finds in the long pits of Friedberg-Bruchenbrücken (Germany), a settlement of the earliest LBK and, for the first time, raised doubts concerning the contemporaneity of LBK houses and the long-pit finds (Stäuble, 1997). Several LBK occupation horizons are known, e.g. Olszanica 
(Milisauskas, 1976), but none of them has so far been excavated in sufficient detail to evaluate the relationship between houses, occupation layers and finds in pits.

In south-east Europe, where occupation layers are more common than in central Europe, occupation layers have often been treated as 'unstratified' and thus of little value for establishing chronologies and investigating the use of space in Neolithic settlements. During the excavations of Ecsegfalva 23, in County Békés (Hungary), detailed recording of finds took place and clear indications of settlement-like concentrations of daub were located, but no distinct structures could be identified (Whittle and Zalai-Gaál, 2007).

In Tăşnad, the coexistence of a thick occupation layer, deep pits and house remains provides ideal conditions for the examination of the relationship between these features in order to answer the difficult questions of how finds get into pits and how they relate to adjacent houses.

The archaeological remains in the area of Tăşnad Spa were not only threatened by building activities for the burgeoning thermal bath, but also by erosion along the Cehal acerbated by the activities of cows which daily climb the increasingly unstable banks of the river on their way to graze in the Cehal valley (Fig. 4). In 2012, the Satu Mare County Museum started rescue excavations on the right bank of the Cehal channel, conducted in cooperation with the UCL Institute of Archaeology, under the direction of Cristian Virag, Ulrike Sommer and Ciprian Astaloş.

After a magnetometry survey, a 10x10m trench was dug to assess both the depth of the occupation layer and the preservation and distribution of Neolithic finds. Six testpits helped to delimit the extent of the settlement and to elucidate the alluvial history of the Cehal river. Evidence of a former riverbed was discovered, and early Iron Age (Gáva) remains, c. $1 \mathrm{~m}$ deep, have allowed us to date the formation of hillwash in the Cehal valley.

The occupation layer is being excavated in a system of quadrants and spits to provide

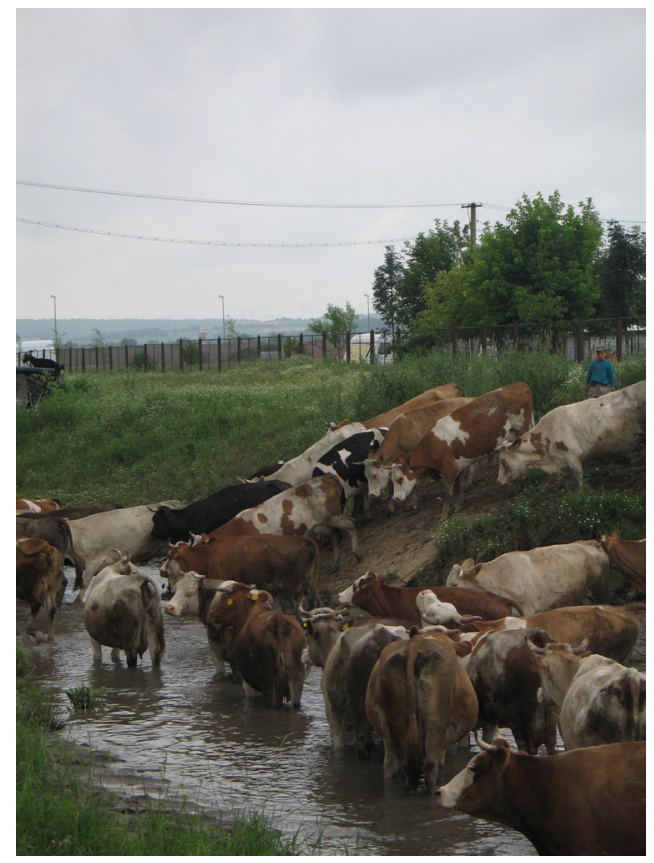

Fig. 4: Erosion of the banks of the Cehal river by grazing cattle (photo: Margrete Johansen).

a close spatial control on the location of finds and botanical remains (Fig. 5). Every find $>1 \mathrm{~cm}$ is recorded three-dimensionally, together with information on its orientation and dip. Thus, it will be possible to reconstruct how the finds were deposited and their subsequent depositional history (cf. Sommer, 1991). Often, several sherds of the same vessel are found close together (Fig. 5), separated by empty space from the next find-concentrations. This is likely to indicate distinct dumping events, perhaps on the site of an abandoned house. The layer below is generally much poorer in finds.

The finds consist mainly of pottery, but daub, hearth remains, ground stone, animal bones and lithics have also been uncovered. Both local raw materials, such as jasper and limnic quartzite, and imported siliceous rocks were used: Hungarian/Slovakian obsidian, blond Balkan flint from north-eastern Bulgaria, and Prut flint from Moldavia or the Ukraine. These indicate the far-flung connections of the early farmers at Tăşnad. 


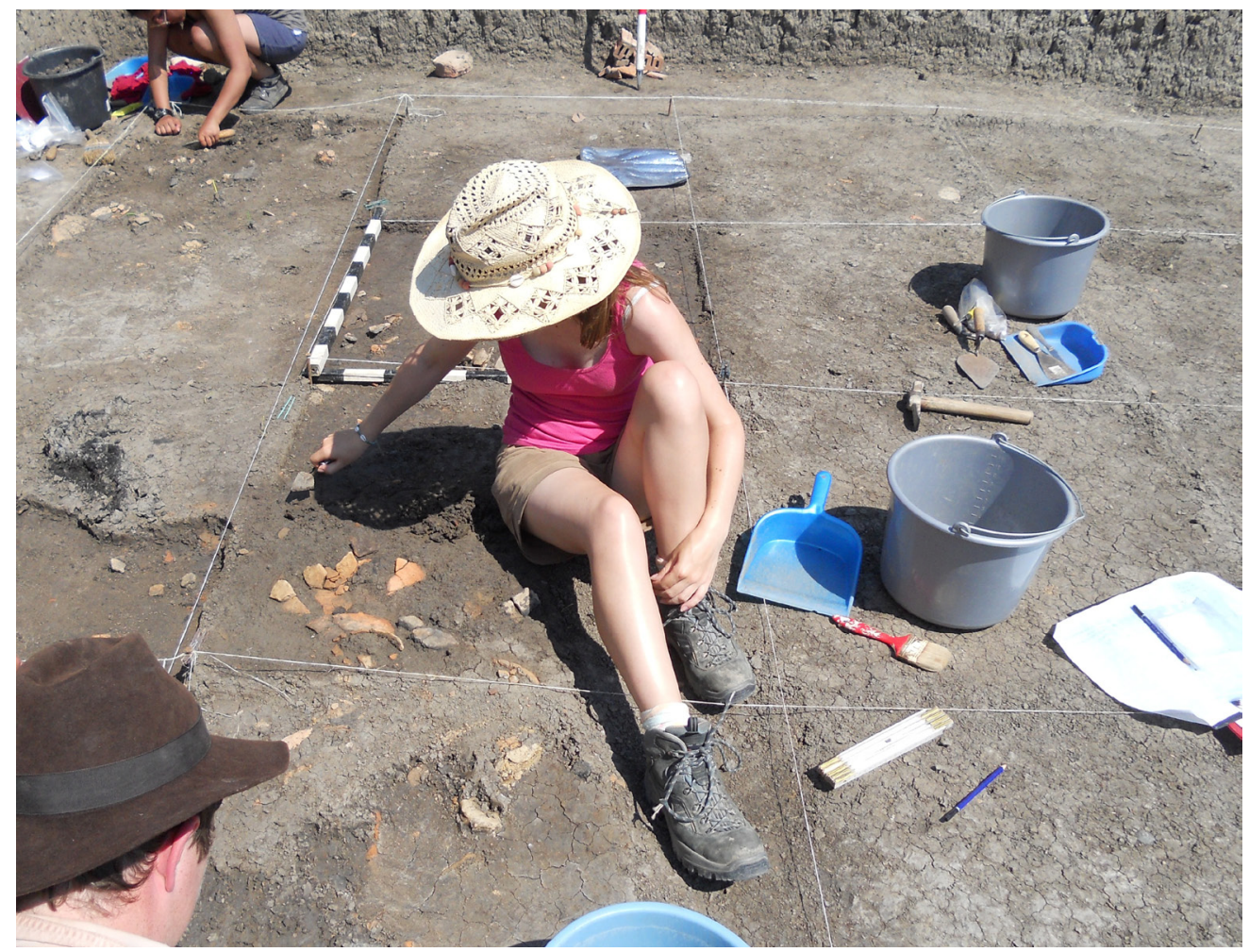

Fig. 5: Excavation of the occupation layer at Tăşnad Sere, 2012 (photo: Ulrike Sommer).

Most of the obsidian pieces are rather small and often cortical. Debitage, as well as formal tools, has been recovered, whereas the blond Balkan flint is only represented by regular blades and blade fragments. In contrast, large obsidian cores were discovered at Căuaş and Urziceni (Németi, 1999: 19); this may point to the existence of specialized settlements or internal trade.

By systematic bucket-flotation, we have recovered plenty of charcoal, but so far very few seeds. Fishbones and the remains of other aquatic resources are similarly missing, running counter to expectation given the riverine environment. This can only be further explored once deeper levels of the site and the contents of pits have been excavated and analysed. Animal bones also remain rare, but have been common in the rescue excavations on the site. They have not yet been analysed; the article of El Susi (2011) is based on a limited selection of finds that is probably not representative.
Already, the excavations are offering tantalising glimpses of daily life in the early Neolithic, but only the detailed mapping of all the different find-categories and their distribution, as well as refitting-studies, will allow us to understand how a Criş settlement actually functioned through time.

\section{References}

Băcueț-Crişan, S and Virag, C 2007 Plastica antropomorfă neolitică din nord-vestul României. in C Găzdac and C Gaiu (eds) Fontes Historiae, Studia in Honorem Demetrii Protease. Bistriţa/Cluj-Napoca: Accent, pp. 43-59.

El Susi, G 2011 The management of livestock in the early Neolithic settlements (Starčevo-Criş complex) from Transylvania and Banat. in S A Luca and C Suciu (eds) Early Neolithic (Starčevo-Criş) Sites on the Territory of Romania. Oxford: Archaeopress, pp. 47-56. 
Gulyás, S, Aniko, T and Sümegi, P 2007 The zooarchaeological analysis of freshwater bivalve shells and their relevance in the life of a Neolithic community. in A Whittle (ed) The Early Neolithic on the Great Hungarian Plain: Investigations of the Körös Culture Site of Ecsegfalva 23, County Békés. Budapest: Archaeological Institute of the Hungarian Academy of Sciences, pp. 395-412.

Gyulai, F 2010. Archaeobotanical research at the Körös culture site of Íbrany-Nagyerdő and its relationship to plant remains from contemporaneous sites in Hungary. in J K Kozłowski and P Raczky (eds) Neolithization of the Carpathian Basin: Northernmost Distribution of the Starčevo/ Körös Culture. Kraków: Polska Akademia Umiejętności; Budapest: Institute of Archaeological Sciences of the Eötvös Loránd University, pp. 219-237.

Iercoşan, N 1995 Săpături arheologice în aşezarea neolitică aparținând culturii Starčevo - Criş de la Tăşnad (jud. Satu Mare). Studii şi Comunicări Satu Mare 11-12 (1994-1995): 9-32.

Kovács, Z E, Gál, E and Bartosiewicz, L 2010 Early Neolithic animal bones from ÍbranyNagyerdő, Hungary. in J K Kozłowski and P Raczky (eds) Neolithization of the Carpathian Basin: Northernmost Distribution of the Starčevo/Körös Culture. Kraków: Polska Akademia Umiejętności/Budapest: Institute of Archaeological Sciences of the Eötvös Loránd University, pp. 238- 254.

Lazarovici, C M and Lazarovici, Gh 2006 Arhitectura neoliticului şi epocii cuprului din România. I. Neoliticul. Academia Română. Iaşi, Filiala Iaşi: Institutul de Arheologie/Trinitas.

Lazarovici, C M and Lazarovici, Gh 2011 Architecture of the early Neolithic in Romania. in S A Luca and C Suciu (eds) Early Neolithic (Starčevo-Criş) Sites on the Territory of Romania. Oxford: Archaeopress, pp. 19-36.

Lazarovici, Gh 1984 Neoliticul timpuriu în România. Acta Musei Porolissensis VIII: 48-104.
Lüning, J 2005 Bandkeramische Hofplätze und absolute Chronologie der Bandkeramik. in J Lüning, C Frirdich and A Zimmermann (eds) Die Bandkeramik im 21. Jahrhundert. Rahden/Westfalen: Leidorf, pp. 49-74.

Milisauskas, S 1976 Archaeological Investigations on the Linear Culture Village of Olszanica. Wrocław: Ossolineum.

Németi, J 1999 Repertoriul arheologic al zonei Careiului. Bibliotheca Thracologica XXVIII. Bucharest: Institutul Român de Tracologie.

Stäuble, H 1997 Häuser, Gruben und Funde der bandkeramischen Siedlung Friedberg-Bruchenbrücken, Wetteraukreis. in J Lüning (ed) Eine Siedlung der Ältesten Bandkeramik in Bruchenbrücken, Stadt Friedberg/Hessen. Universitätsforschungen zur prähistorischen Archäologie 39. Bonn: Habelt, pp. 17-150.

Stehli, P 1994 Chronologie der Bandkeramik im Merzbachtal. in J Lüning and P Stehli (eds) Die Bandkeramik im Merzbachtal auf der Aldenhovener Platte. Rheinische Ausgrabungen 36. Köln: Rheinland-Verlag, pp. 79-191.

Schubert, H 1999 Die bemalte Keramik des Frühneolithikums in Südosteuropa, Italien und Westanatolien. Internationale Archäologie 47. Rahden/Westfalen: Leidorf.

Sommer, U 1991 Zur Entstehung archäologischer Fundvergesellschaftungen, Versuch einer archäologischen Taphonomie. Studien zur Siedlungsarchäologie I. Universitätsforschungen zur Prähistorischen Archäologie 6. Bonn: Habelt, pp. 51-193.

Whittle, A and Zalai-Gaál, I 2007 Excavations at Ecsegfalva 23. in A Whittle (ed) The Early Neolithic on the Great Hungarian Plain. Investigations of the Körös Cul ture Site of Ecsegfalva 23, County Békés. Varia Archaeologica Hungarica 21. Budapest: Archaeological Institute of the Hungarian Academy of Sciences, pp. 138-171. 
How to cite this news: Astaloş, C, Sommer, U and Virag, C 2013 Excavations of an Early Neolithic Site at Tăşnad, Romania. Archaeology International, No. 16 (2012-2013): 47-53, DOI: http://dx.doi. org/10.5334/ai.1614

Published: 24 October 2013

Copyright: ( 2013 The Author(s). This is an open-access article distributed under the terms of the Creative Commons Attribution 3.0 Unported License (CC-BY 3.0), which permits unrestricted use, distribution, and reproduction in any medium, provided the original author and source are credited. See http://creativecommons.org/licenses/by/3.0/.

$\mathrm{u}[\quad$ Archaeology International is a peer-reviewed open access journal ] $\mathrm{u}\left[\begin{array}{l}\text { Archaeology International } \\ \text { published by Ubiquity Press }\end{array}\right.$ 